Удк 65.012.12

DOI: https://doi.org/10.32851/2708-0366/2020.3.8

Бояринова К.О. доктор економічних наук, доцентка, доцентка кафеедри менеджменту,

Національний технічний університет України «Київьький політехнічний інститут імені Ігоря Сікорського»

ORCID: https://orcid.org/0000-0001-5879-2213

Бордюг К.С. магістрант,

Національний технічний університет України «Київський політехнічний інститут імені Ігоря Сікорського»

\author{
Boiarynova Kateryna \\ National Technical University of Ukraine \\ "lgor Sikorsky Kyiv Polytechnic Institute» \\ Bordiuh Kateryna \\ National Technical University of Ukraine \\ "lgor Sikorsky Kyiv Polytechnic Institute»
}

\title{
ПРОГРАМНО-ЦІЛЬОВИЙ ПІДХІД \\ В УПРАВЛІННІ ЕКОНОМІЧНОЮ БЕЗПЕКОЮ ПІДПРИЄМСТВ
}

\author{
PROGRAM-TARGET APPROACH \\ IN MANAGING ECONOMIC SECURITY OF ENTERPRISES
}

Статтю присвячено узагальненню та обгрунтуванню доцільності застосування програмно-иільового підходу в управлінні економічною безпекою підприємств, встановленню цільових його орієнтирів та відповідних програмних заходів їх досягнення. Визначено програмні заходи для досягнення иілей управління фінансовою безпекою підприємства, у тому числі для зниження кредитозалежності, підвищення ефективності інвестицій. Розкрито програмні заходи для забезпечення техніко-технологічної безпеки, зокрема для забезпечення досягнення безперебійності процесу виробництва. Обгрунтовано програмні заходи иілей управління інформаційною безпекою (захист розробок та ноу-хау; захист від конкурентної розвідки) та програмні заходи цілей кадрової безпеки. Запропоновано відповідні цілі та програмні заходи безпеки економічних відносин.

Ключові слова: економічна безпека, програмно-цуільовий підхід, управління, підприємство, програмні заходи.

Статья посвящена обобщзению и обоснованию целесообразности применения программно-целевого подхода в управлении экономической безопасностью предприятий, установлению иелевых его ориентиров и соответствуюших программных мероприятий их достижения. Определены программные мероприятия для достижения иелей управления финансовой безопасностью предприятия, в том числе для снижения кредитозависимости, повышения эффективности инвестииий. Раскрыты программные мероприятия в иелях обеспечения технико-технологической безопасности, в частности для обеспечения достижения бесперебойности прочесса производства. Обосновань программные мероприятия целей управления информационной безопасностью (зашита разработок $u$ ноу-хау, защчта от конкурентной разведки) и программные мероприятия ціелей кадровой безопасности. Предложены соответствующие иели и программные меры безопасности экономических отночений.

Ключевые слова: экономическая безопасность, программно-цуелевой подход, управление, предприятие, программные мероприятия. 
The article is devoted to the generalization and substantiation of expediency of application of the program-target approach in management of economic safety of the enterprises, establishment of its target landmarks and the corresponding program measures of achievement of the purposes. It is determined the goals and appropriate measures of financial security: management maintaining and increasing the net profit of the enterprise (goal) - the implementation of policies to reduce receivables (program activities); reduction of credit dependence-attracting investors to the enterprise; increase the efficiency of investments - the distribution of investments between different investment objects. The purposes and program actions for technical and technological safety are revealed: ensuring the quality - replacement and use of new wear-resistant materials, introduction of automated tracking systems; achieving uninterrupted production process - the use of the complex "Smart Factory". It is determined the goals and appropriate measures of information security: limitation and leveling of information leakage-introduction of information protection systems; preservation of trade secrets, developments and know-how - concluding agreements on non-disclosure of secrets with staff, protection of intellectual property; protection against competitive intelligence - controlling the flow of information in the business environment. Target guidelines and program measures of personnel security are substantiated: increase of intellectual potential - introduction "corporate university". The goals and program measures of economic relations security are offered: increase of efficiency of interaction with partners mutual support in case of force majeure, quality control of contractors; effective interaction with counterparties - observance of integrity in mutual relations; with suppliers - quality control of raw materials, components; establishment of mutually beneficial terms of delivery; observance of investors' integrity - observance by investors of volumes and terms of investment investments.

Key words: economic security, program-target approach, management, enterprise, program measures.

Постановка проблеми. В умовах турбулентних змін, невизначеності та швидкої мінливості умов функціонування підприємств особливого значення набуває управління забезеченням їхньої економічної безпеки. Серед методів і способів управління особливим підходом, який поєднує цільову орієнтацію та програму заходів із досягнення цілей, вважається програмно-цільовий.

Аналіз останніх досліджень і публікацій. Питання застосування програмно-цільового підходу в управлінні економічною безпекою розкриваються науковцями як на макро-, так і на макрорівні. Зокрема, Н.В. Галайко обгрунтовує необхідність застосування програмно-цільового методу в системі управління економічною безпекою України [1]; Л.О. Волощуком розроблено принципово нову класифікацію підходів до формування аналітичних інструментів управління економічною безпекою промислового підприємства [2]. О.А. Антонян, С.М. Афанасьєва здійснили порівняльний аналіз різних підходів до оцінювання рівня економічної безпеки підприємств, у тому числі й обгрунтували застосування програмно-цільового [3]. Науковцями 3 різних позицій розглядається як забезпечення економічної безпеки, так і різні підходи до управління цим процесом. Проте програмно-цільовий підхід залишається актуальним напрямом досліджень. Управління економічною безпекою на основі застосування програмноцільового підходу потребує конкретизації цілей за кожним складником економічної безпеки з визначенням тих програмних заходів, які забезпечать їх досягнення.

Формулювання цілей статті. Метою дослідження $є$ узагальнення та обгрунтування доцільності застосування програмно-цільового підходу в управлінні економічною безпекою підприємств, встановлення цільових його орієнтирів та відповідних програмних заходів досягнення цілей.

Виклад основного матеріалу. Розвиток підприємства та його ефективне функціонування залежить від встановлених цілей. Цільова орієнтація діяльності підприємства формує основу для розроблення планів усіх рівнів - стратегічного, тактичного та оперативного. Поміж цілей вагомого значення для забезпечення економічної безпеки підприємства набуває формування програми як інструменту планування досягнення встановлених цілей. Під нею науковцями розуміється установлення певної послідов- 
ності етапів, порядку й механізмів управління процесом послідовного вирішення проблеми [4], урегульованим згідно з витрачанням ресурсів, виконавцями і термінами здійснення комплексу соціально-економічних, виробничих, науково-технічних, організаційно-господарських, інших завдань та заходів, спрямованих на вирішення проблем найбільш ефективним способом у визначений термін [5]. За поєднання встановлених цілей та програм їх досягнення формується програмно-цільовий підхід до управління. Програмно-цільовий підхід вважається сукупністю важелів досягнення конкретних цілей (бажаних кінцевих результатів), які забезпечують узгодженість систем заходів із поставленими цілями шляхом проведення аналізу цих цілей і включення у план їх реалізації усіх необхідних виконавців, незалежно від приналежності [6]. Загалом програмно-цільовий підхід є таким підходом, який враховує причинно-наслідкові зв'язки реалізації певних економічних та управлінських дій та реалізується на основі досягнення встановлених цілей шляхом виконання комплексу логічно-упорядкованих заходів.

Програмно-цільовий підхід у ракурсі економічної безпеки застосовується у двох напрямах: у системі управління та в системі оцінювання.

3 позиції управління програмно цільовий підхід грунтується на низці принципів. Їх змістовно розкриває у своїй праці Н.В. Галайко. Такі принципи можуть бути використані і як орієнтири для програмних заходів забезпечення економічної безпеки підприємства (табл. 1).

3 позиції оцінювання економічної безпеки застосування програмно-цільового підходу науковці вважають ускладненим (табл. 2). Проте, на нашу думку, саме він спроможний надати можливість проаналізувати економічну безпеку не тільки з позиції статики отриманих результатів, але у й контексті цільової інтерпретації цих результатів. Вважаємо, що у систему оцінювання варто вводити не тільки визначення показників, але й порівняння фактичних даних із плановими, встановленими відповідно до стратегічних та тактичних цілей забезпечення економічної безпеки підприємства.

Реалізація програмно-цільового підходу в управлінні економічною безпекою має здійснюватися на основі інтегрування цілей, які ставить перед собою підприємство щодо нівелювання ризиків настання несприятливих умов, утримання позицій на ринку, утримання відповідного рівня прибутковості, наявності ресурсів та кадрового забезпечення для безперебійного функціонування і розвитку, а також спланованої програми заходів, системно вмонтованої у повсякденну діяльність підприємства, які забезпечать стійке функціонування у майбутньому. Відповідно до зазначеного кожна структурна складова частина 3 позиції управління економічною безпекою має мати цілі та відповідний їм комплекс програмних заходів.

Фінансова безпека. Ключовою метою забезпечення фінансової безпеки є втримання та нарощення чистого прибутку та рентабельності підприємства у змінних умовах господарювання. Інструментом забезпечення фінансової безпеки є фінансовий потенціал та фінансові ресурси, які є об'єктами побудови програми. Її комплекс заходів має бути спрямований на зменшення ризиків банкрутства, падіння прибутковості, зниження кредитозалежності в умовах нестійкої фінансової системи як підприємства, так і країни. Іншим напрямом заходів програми $є$ нівелювання значного рівня дебіторської заборгованості підприємств клієнтів, зменшення співвідношення залученого та власного капіталу у напрямі зростання останнього. Варто також концентруватися на зниженні ризиків інвестування підприємства, оцінюючи на належному рівні інвестиційні ризики, страхуванні капіталу та ризикованих фінансових вкладень, застосуванні системи бюджетування проектів. Загалом цілі та програмні заходи забезпечення фінансової безпеки підприємства наведено на рис. 1

Техніко-технологічна економічна безпека. 3 підвищенням рівня вимог до якості продукції та послуг підвищується і рівень вимог до техніко-технологічного забезпечення 
Таблиця 1

Принципи програмно-цільового підходу в управлінні

\begin{tabular}{|c|c|c|}
\hline Принцип [1] & Характеристика [1] & $\begin{array}{c}\text { Ключовий напрям у ракурсі } \\
\text { економічної безпеки }\end{array}$ \\
\hline $\begin{array}{l}\text { Цілеспря- } \\
\text { мованість і } \\
\text { цілеобгрун- } \\
\text { тування }\end{array}$ & $\begin{array}{l}\text { Увага приділяється поглибленому } \\
\text { проробленню цілей, їх структури- } \\
\text { зації, обліку правових і соціаль- } \\
\text { но-економічних обмежень, ран- } \\
\text { жируванню цілей і встановленню } \\
\text { найбільш пріоритетних із них, а } \\
\text { також цільовій орієнтації на досяг- } \\
\text { нення поставлених результатів }\end{array}$ & $\begin{array}{l}\text { Забезпечення економічної безпеки за } \\
\text { ключовими цільовими напрямами в } \\
\text { умовах наявності значної кількості за- } \\
\text { гроз та ризиків }\end{array}$ \\
\hline Системність & $\begin{array}{l}\text { У межах системного підходу осо- } \\
\text { блива увага приділяється враху- } \\
\text { ванню взаємодій і взаємозв'язків, } \\
\text { які можуть виникнути під час ре- } \\
\text { алізації програми }\end{array}$ & $\begin{array}{l}\text { Реалізація програм забезпечення еконо- } \\
\text { мічної безпеки має бути взаємоузгодже- } \\
\text { на зі складовими напрямами діяльності } \\
\text { підприємства (фінанси, виробництво, } \\
\text { маркетинг тощо) як цілісної виробни- } \\
\text { чо-економічної системи }\end{array}$ \\
\hline $\begin{array}{l}\text { Цільовий } \\
\text { розподіл }\end{array}$ & $\begin{array}{l}\text { Проводиться ефективний розподіл } \\
\text { необхідних ресурсів і витрат у су- } \\
\text { ворій відповідності із цілями }\end{array}$ & $\begin{array}{l}\text { Витрати на забезпечення економічної } \\
\text { безпеки мають бути розподілені між за- } \\
\text { ходами реалізації програми, системно } \\
\text { врегульованими за процесом витрачан- } \\
\text { ня ресурсів із відповідним належним } \\
\text { контролем плану/факту }\end{array}$ \\
\hline $\begin{array}{l}\text { Комплекс- } \\
\text { ність }\end{array}$ & $\begin{array}{l}\text { Припускає облік усіх факторів, що } \\
\text { впливають на досягнення постав- } \\
\text { лених цілей, а також досягнення } \\
\text { приватних цілей програми відпо- } \\
\text { відно до загальних цілей }\end{array}$ & $\begin{array}{l}\text { За забезпечення економічної безпеки } \\
\text { в умовах нестабільності варто вра- } \\
\text { ховувати вплив як факторів безпо- } \\
\text { середнього бізнес-середовища під- } \\
\text { приємства, так і факторів зовнішнього } \\
\text { середовища опосередкованого впливу, } \\
\text { відстежуючи тенденції змін }\end{array}$ \\
\hline Своєчасність & $\begin{array}{l}\text { Досягнення кінцевих результатів } \\
\text { повинне бути своєчасним і відпо- } \\
\text { відати плану заходів }\end{array}$ & $\begin{array}{l}\text { Вчасна реалізація програмних заходів із } \\
\text { дотримання відповідного рівня еконо- } \\
\text { мічної безпеки дасть змогу забезпечити } \\
\text { підприємству безперебійне функціону- } \\
\text { вання }\end{array}$ \\
\hline
\end{tabular}

Джерело: складено з застосуванням [1]

Таблиця 2

\section{Програмно-цільовий підхід}

як метод оцінювання економічної безпеки підприємства

\begin{tabular}{|l|l|l|}
\hline \multicolumn{1}{|c|}{ Автор } & \multicolumn{1}{|c|}{ Підхід до використання } & \multicolumn{1}{|c|}{ Процедури } \\
\hline Волощук Л.О. [2] & $\begin{array}{l}\text { Базується на порівнянні фактич- } \\
\text { них показників із цільовими орі- } \\
\text { єнтирами, що визначені умовами } \\
\text { економічно безпечного стану під- } \\
\text { приємства }\end{array}$ & $\begin{array}{l}\text { Відбір показників економічної без- } \\
\text { пеки, визначення методів ї інтегру- } \\
\text { вання, встановлення коефіцієнтів } \\
\text { значущості часткових показників }\end{array}$ \\
\hline Сак Т.В. [7] & $\begin{array}{l}\text { Ірунтується на інтегруванні показ- } \\
\text { ників, які визначають рівень еко- } \\
\text { номічної безпеки підприємства }\end{array}$ & $\begin{array}{l}\text { Відбір показників економічної без- } \\
\text { пеки, визначення методів їх інтегру- } \\
\text { вання, встановлення вагових коефі- } \\
\text { цієнтів }\end{array}$ \\
\hline $\begin{array}{l}\text { Антонян О.А., } \\
\text { Афанасьєва С.М. } \\
\text { [3] }\end{array}$ & $\begin{array}{l}\text { Відображає принципи та умови } \\
\text { управління та розвитку підприєм- } \\
\text { ства }\end{array}$ & $\begin{array}{l}\text { Використання інтегрованої сукуп- } \\
\text { ності показників економічної безпе- } \\
\text { ки (можливо, і у розрізі їі видів) }\end{array}$ \\
\hline
\end{tabular}

Складено на основі [2; 3; 7] 
підприємства. Об'єктами техніко-технологічної безпеки стають фактори виробництва технічного та технологічного змісту. Цілями забезпечення техніко-технологічної безпеки є надання послуг чи виробництво продукції належного рівня якості, безперебійність процесу виробництва, будівництва, створення продукції, енергоощадливість обладнання та технологій (рис. 2). Тому програмними заходами є списання застарі-

\begin{tabular}{|c|c|}
\hline Цілі & Програмні заходи \\
\hline$\rightarrow \quad \begin{array}{c}\text { Утримання та підвищення } \\
\text { чистого прибутку підприємства }\end{array}$ & $\begin{array}{l}\text { Реалізація політики взаємовідносин } 3 \\
\text { підприємствами-споживачами на засадах } \\
\text { зниження дебіторської заборгованості, } \\
\text { застосування передоплати у виконані } \\
\text { послуг/постачання продукції }\end{array}$ \\
\hline$\rightarrow \begin{array}{c}\text { Підвищення рентабельності } \\
\text { підприємства }\end{array}$ & $\begin{array}{l}\text { Оптимізація витрат, зниження собівартості } \\
\text { завдяки новим технологіям та конструкторсько- } \\
\text { технічним рішенням }\end{array}$ \\
\hline$\rightarrow$ Зниження кредитозалежності & $\begin{array}{l}\text { Залучення інвесторів у діяльність підприємства, } \\
\text { реалізація спільних партнерських проектів }\end{array}$ \\
\hline$\rightarrow \quad \begin{array}{c}\text { Підвищення ефективності } \\
\text { інвестицій }\end{array}$ & $\begin{array}{l}\text { Розподіл інвестицій між різними об’єктами } \\
\text { вкладень, ретельний аналіз напрямів } \\
\text { інвестиційних вкладень на до інвестицій фазі, } \\
\text { введення бюджетування проектів }\end{array}$ \\
\hline
\end{tabular}

Рис. 1. Цілі та програмні заходи забезпечення фінансової безпеки підприємства Джерело: складено авторами

\begin{tabular}{|c|c|}
\hline Цілі & Програмні заходи \\
\hline $\begin{array}{l}\text { Забезпечення якості } \\
\text { послуг/продукції }\end{array}$ & $\begin{array}{l}\text { Заміна та використання нових зносостійких та } \\
\text { пожежостійких матеріалів, впровадження } \\
\text { автоматизованих систем відслідковування браку, } \\
\text { системна перевірка якості ресурсів }\end{array}$ \\
\hline $\begin{array}{l}\text { Досягнення безперебійності } \\
\text { процесу виробництва }\end{array}$ & $\begin{array}{l}\text { Регулярна заміна застарілого обладнання, у разі } \\
\text { морального зносу - до терміну списання, } \\
\text { налагодження системи вчасного проведення } \\
\text { ремонтних робіт, використання лізингу у разі } \\
\text { обмеженості фінансових ресурсів, застосування } \\
\text { комплексу «Розумна фабрика» }\end{array}$ \\
\hline та технологій & $\begin{array}{l}\text { Запровадження технологій енергоощадливості, } \\
\text { встановлення обладнання, яке її забезпечує }\end{array}$ \\
\hline
\end{tabular}

Рис. 2. Цілі та програмні заходи забезпечення техніко-технологічної безпеки підприємства Джерело: складено авторами 
лого обладнання, яке може призвести до неякісного виконання робіт, браку продукції тощо; активізація реалізації лізингових проектів на підприємстві, що за умов обмеженості фінансових ресурсів спроможні покращити матеріальну базу; вчасна заміна інвентарю, відстежування його фізичної зношеності; заміна та використання нових зносостійких та пожежостійких матеріалів.

Інформаційна безпека. Цілями інформаційної безпеки підприємства є створення такого інформаційного середовища на підприємстві, яке б унеможливлювало витік інформації, конкурентної розвідки, збереження комерційної таємниці. Отже, об’єктом інформаційної безпеки є інформація підприємства у різних її проявах у процесі діяльності. Програмними заходами для ії забезпечення є утримання відповідної служби, укладання угод із працівниками про нерозголошення таємниць, понесення відповідальності, патентування розробок, впровадження різного роду програмного забезпечення, що унеможливлює витік інформації, використання різноаспектних систем захисту інформації, відстежування інформаційного потоку підприємства в бізнес-середовищі, а також відстежування інформації, яка надається про підприємство іншими організаціями та в медіапросторі для нівелювання можливості спотворення іміджу (рис. 3).

Кадрова безпека. Об'єктами такої безпеки є не тільки безпосередньо персонал підприємства, але й система наявних трудових відносин, організована система оплати праці, участь працівників у капіталі. Цілями ії забезпечення є: а) підвищення інтелектуального потенціалу та професіоналізму працівників завдяки застосуванню відповідної корпоративної культури, впровадження технологій навчання на базі «корпоративного університету»; б) ефективна кадрова політика в системі реалізації трудових відносин, що потребує впровадження таких програмних заходів, як урегульованість робочого дня, віддалена робота персоналу, система надання соціального пакету; в) підвищення зацікавленості персоналу у розвитку підприємства через участь працівників у капіталі, використання сучасних технологій мотивування та стимуляційних заходів (рис. 4).

\begin{tabular}{|c|c|}
\hline \multicolumn{1}{|c|}{ Цілі } & \multicolumn{1}{c|}{ Програмні заходи } \\
\hline $\begin{array}{c}\text { Обмеженість та нівелювання } \\
\text { витоку інформації }\end{array}$ & $\begin{array}{l}\text { Впровадження систем захисту інформації, } \\
\text { програмних продуктів безпечного її обігу }\end{array}$ \\
\hline Збереження комерційної & $\begin{array}{l}\text { Персоналом та понесення відповідальності у } \\
\text { разі такого, навчання системі інформаційної }\end{array}$ \\
\hline $\begin{array}{c}\text { таємниці, розробок та ноу-хау } \\
\text { безпеки, впровадження системи захисту } \\
\text { об'єктів інтелектуальної власності }\end{array}$ \\
\hline $\begin{array}{c}\text { Захист від конкурентної } \\
\text { розвідки }\end{array}$ & $\begin{array}{l}\text { Контролювання інформаційного потоку в } \\
\text { бізнес-середовищі підприємства, } \\
\text { відслідковування характеристик підприємства } \\
\text { в інформаційному просторі }\end{array}$ \\
\hline
\end{tabular}

Рис. 3. Цілі та програмні заходи забезпечення інформаційної безпеки підприємства Джерело: складено авторами 


\begin{tabular}{|c|c|}
\hline Цілі & Програмні заходи \\
\hline $\begin{array}{c}\text { Підвищення інтелектуального } \\
\text { потенціалу та професіоналізму }\end{array}$ & $\begin{array}{l}\text { Дотримання корпоративної культури, } \\
\text { впровадження технологій навчання на базі } \\
\text { «корпоративного університету» }\end{array}$ \\
\hline $\begin{array}{c}\text { Ефективна кадрова політика в } \\
\text { системі трудових відносин }\end{array}$ & $\begin{array}{l}\text { Урегулювання робочого дня, віддаленої } \\
\text { роботи персоналу, укомплектування } \\
\text { соціального пакету відповідно потребам } \\
\text { працівників }\end{array}$ \\
\hline $\begin{array}{c}\text { Підвищення зацікавленості } \\
\text { персоналу у розвитку } \\
\text { підприємства }\end{array}$ & $\begin{array}{l}\text { Запровадження системи участі працівників у } \\
\text { капіталі підприємства, використання } \\
\text { грейдування посад, конкурентної кооперації }\end{array}$ \\
\hline
\end{tabular}

Рис. 4. Цілі та програмні заходи забезпечення кадрової безпеки підприємства Джерело: складено авторами

\begin{tabular}{|c|c|}
\hline Цілі & Програмні заходи \\
\hline $\begin{array}{c}\text { Підвищення ефективності } \\
\text { взаємодії з партнерами }\end{array}$ & $\begin{array}{l}\text { Дотримання соціальної відповідальності як } \\
\text { підприємства, так і партнерів; } \\
\text { взаємопідтримка за форс мажорних обставин, } \\
\text { контролювання якості виконання робіт } \\
\text { підрядників, перевірка відповідності } \\
\text { розробленої проектно-конструкторської } \\
\text { документації }\end{array}$ \\
\hline $\begin{array}{c}\text { Ефективна взаємодія з } \\
\text { контрагентами }\end{array}$ & $\begin{array}{l}\text { Дотримання доброчесності у взаємовідносинах } \\
\text { між суб’єктами ринку, вчасне та якісне } \\
\text { виконання предмету укладених угод; дотримання } \\
\text { довгострокових відносин }\end{array}$ \\
\hline $\begin{array}{c}\text { Ефективна взаємодія з } \\
\text { постачальниками }\end{array}$ & $\begin{array}{l}\text { Контролювання та перевірка сертифікатів } \\
\text { якості сировини, матеріалів, комплектуючих; } \\
\text { укладення довгострокових угод, встановлення } \\
\text { взаємовигідних термінів постачання }\end{array}$ \\
\hline $\begin{array}{c}\text { Дотримання доброчесності } \\
\text { інвесторів }\end{array}$ & $\begin{array}{l}\text { Дотримання інвесторами обсягів та термінів } \\
\text { інвестиційних вкладень, відстоювання } \\
\text { порушення укладених угод у судовому } \\
\text { порядку, стягнення збитків у разі порушення } \\
\text { умов інвестиційних контрактів }\end{array}$ \\
\hline
\end{tabular}

Рис. 5. Цілі та програмні заходи

забезпечення безпеки економічних відносин підприємства

Джерело: складено авторами 
Безпека економічних відносин. Цілями безпеки економічних відносин є ефективна контрактна діяльність, надійність партнерів та контрагентів, якість послуг та продукції постачальників, належний рівень професіоналізму проектних організацій. Об'єктами безпеки економічних відносин є відносини з партнерами, інвесторами, іншими стейкхолдерами, контрагентами та постачальниками. Відповідно програма забезпечення такої діяльності націлена на формування системної взаємодії, укладання довгострокових контрактів, контролювання та перевірку сертифікатів якості сировини та матеріалів у постачальників, відповідності термінів постачання визначеним підприємством термінам, відповідність розробленої проектної документації тощо (рис. 5). Крім того, варто враховувати наявність відносин і з інвесторами, метою чого $є$ дотримання їхньої доброчесності. Відповідно програмні заходи мають бути спрямовані на дотримання інвесторами обсягів та термінів інвестиційних вкладень, відстоювання порушення укладених угод у судовому порядку, стягнення збитків у разі порушення умов інвестиційних контрактів.

Застосування програмно-цільового підходу до управління економічною безпекою на поєднанні взаємозв'язків цілей та програмних заходів дасть змогу підприємству іiї системно забезпечувати.

Висновки. Таким чином, саме програмно-цільовий підхід до управління економічною безпекою підприємства надає можливість інтегрувати ії цільові орієнтири та програмні заходи. При цьому їхня система має включати заходи, орієнтовані на об'єкти кожної складової частини економічної безпеки. Формування програми дій на основі причинно-наслідкових зв'язків із цілями економічної безпеки дасть підприємству безперебійно функціонувати, нівелювати ризики настання несприятливих ситуацій та підтримувати стійке положення на ринку.

\section{Список використаних джерел:}

1. Галайко Н.В. Програмно-цільовий метод у системі управління економічною безпекою України. Науковий вісник Львівського державного університету внутрішніх справ. 2020. № 1. C. 207-213.

2. Волощук Л.О. Класифікація підходів та методів формування аналітичних інструментів оцінювання економічної безпеки промислового підприємства. Економіка: реалії часу. Науковий журнал. 2014. № 5 (15). С. 224-231. URL: http://economics.opu.ua/files/archive/2014/n5.html (дата звернення 25.09.2020).

3. Антонян О.А., Афанасьєва С.М. Підходи до оцінювання рівня економічної безпеки підприємств: порівняльний аналіз. Восточно-Европейский журнал передовых технологий. 2013. 6/3 (66). C. $30-34$.

4. Програмно-цільовий метод у бюджетному процесі / М.Я. Азаров, Ф.О. Ярошенко, О.І. Амоша (кер. авт. кол.). Т. 4. Київ : НДФІ, 2004. 368 с.

5. Кочкаров Р.А. Целевые программы: инструментальная піддержка; Фин. акад. при Пр-ве РФ. Москва : ЗАО «Изд-во «Экономика»», 2007. 223 с

6. Хоронжий А., Євтушок О. Підходи до наукових досліджень систем інформації підприємств. Проблеми становлення інформаиійної економіки в Украӥні: Матеріали IV міжнародної науково-практичної конференції, 17-18 жовтня 2019 р., м. Львів. Львів : ЛНУ імені Івана Франка, 2019. С. 208-211.

7. Сак Т.В. Діагностування рівня економічної безпеки підприємства в умовах обмеженості інформації. Глобальні та національні проблеми економіки. 2015. Вип. 3. С. 404-408.

\section{References:}

1. Halayko N.V. (2020) Prohramno-tsil'ovyy metod u systemi upravlinnya ekonomichnoyu bezpekoyu Ukrayiny [Program-target method in the economic security management system of Ukraine]. Naukovyy visnyk L'vivs'koho derzhavnoho universytetu vnutrishnikh sprav, no. 1, pp. 207-213.

2. Voloshchuk L.O. (2014) Klasyfikatsiya pidkhodiv ta metodiv formuvannya analitychnykh instrumentiv otsinyuvannya ekonomichnoyi bezpeky promyslovoho pidpryyemstva [Classification of approaches and methods of formation of analytical tools for assessing the economic security of an 
industrial enterprise]. Ekonomika: realiyi chasu. Naukovyy zhurnal, no. 5 (15), pp. 224-231. Available at: http://economics.opu.ua/files/archive/2014/n5.html (accessed 25 September 2020).

3. Antonyan O.A., Afanas'yeva S.M. (2013) Pidkhody do otsinyuvannya rivnya ekonomichnoyi bezpeky pidpryyemstv: porivnyal'nyy analiz [Approaches to assessing the level of economic security of enterprises: a comparative analysis]. Vostochno-Evropeyskyy zhurnal peredovykh tekhnolohyy, no. $6 / 3$ (66), pp. 30-34.

4. Prohramno-tsil'ovyy metod $\mathrm{u}$ byudzhetnomu protsesi [Program-target method in the budget process] (2004) / M.YA. Azarov, F.O. Yaroshenko, O.I. Amosha (ker. avt. kol.). T. 4. Kyiv: NDFI, $368 \mathrm{p}$.

5. Kochkarov R.A. (2007) Tselevye prohrammy: ynstrumental'naya podderzhka [Target programs: instrumental support]; Fyn. akad. pry Pr-ve RF. Moscow: ZAO «Yzd-vo «Ékonomyka»», 223 p.

6. Khoronzhyy A., Yevtushok O. (2019) Pidkhody do naukovykh doslidzhen' system informatsiyi pidpryyemstv [Approaches to research of enterprise information systems]. Problemy stanovlennya informatsiynoyi ekonomiky v Ukrayini: Materialy IV mizhnarodnoyi naukovo-praktychnoyi konferentsiyi, 17-18.10.2019 y., L'viv. L'viv: LNU imeni Ivana Franka, pp. 208-211.

7. Sak T.V. (2015) Diahnostuvannya rivnya ekonomichnoyi bezpeky pidpryyemstva $v$ umovakh obmezhenosti informatsiyi [Diagnostics of the enterprise economic security level with limited information available]. Hlobal'ni ta natsional'ni problemy ekonomiky, vol. 3, pp. 404-408. 